\title{
Transparency in IPO mechanism: Retail investors' participation, IPO pricing and returns
}

\author{
Suman Neupane ${ }^{a^{*}}$, Sunil S. Poshakwale ${ }^{\mathrm{b}}$ \\ ${ }^{a}$ Department of Accounting, Finance and Economics, Griffith Business School, Griffith University, \\ 4122, Brisbane, Australia \\ ${ }^{b}$ Centre for Research in Economics and Finance, Cranfield School of Management, Cranfield
}

University, MK43 OAL, United Kingdom

This version: $7^{\text {th }}$ March, 2012

\begin{abstract}
:
Using data from the transparent Indian IPO setting, the paper examines retail investors' participation, their influence on IPO pricing and the returns they make on IPO investment. The transparency in the mechanism, which allows investors to observe prior investors' participation, leads to demand which is concentrated at either one or two points of the offer price range. Analysis of investors' demand during the offer period shows that the participation of retail investors is significantly influenced by the participation of institutional investors. We examine IPO pricing and find that favourable demand by retail investors is positively associated with a high IPO price even after controlling for demand by institutional investors. Further, we find that due to aggressive bidding by overconfident investors, retail investors are, on average, unlikely to make positive allocation weighted initial returns even in a setting where they do not have to compete with institutional investors. Retail investors, however, can earn significant positive allocation weighted initial returns if they limit their participation in IPOs with above average institutional investors' demand.
\end{abstract}

JEL classification: G24; G28; G32

Keywords: Initial public offerings; Transparency; Retail investors; IPO pricing; Winner's curse

* Corresponding author. Tel.: +61 737353 500; fax: +61 737353719.

E-mail addresses: s.neupane@griffith.edu.au (S. Neupane), sunil.poshakwale@cranfield.ac.uk (S. S. Poshakwale). 


\section{Introduction}

Despite the vast literature on Initial Public Offerings (IPOs), we still know very little about investors' participation and their influence in the setting of IPO prices. While a number of important theoretical models, i.e., Rock's (1986) winners' curse hypothesis and Benveniste and Spindt's (1989) information extraction hypothesis, crucially rely on the segregation and varied participation of informed and uninformed investors, little empirical evidence is available. This is, perhaps, due to the opaque nature of the US style bookbuilding mechanism that is widely used across many markets. In this paper, we analyse investors' participation, and in particular, retail investors' participation and their influence on IPO pricing in a setting which is far more transparent than the bookbuilding mechanism in the US.

The Indian IPO market distinguishes itself from others in one important aspect ${ }^{1}$. Unlike the bookbuilding mechanism in US, the IPO mechanism in India is far more transparent. This transparency in the mechanism allows investors to observe two important pieces of information on a real time basis. First, investors can observe the aggregate demand at different points of the offer price range. Second, investors can also observe demand multiples (oversubscription) of different investor categories for their respective portion of the offer. Regulation requires Indian IPO firms to reserve and allocate a pre-determined quota of shares to three different investor categories: qualified institutional investors (QIBs), non-institutional investors (NIIs) and retail investors (RIIs) ${ }^{2}$.

\footnotetext{
${ }^{1}$ We discuss the transparency in the IPO mechanism and other institutional features in detail in Section 3.

2 Qualified institutional investors (QIBs) are large institutional investors registered with SEBI, while noninstitutional investors (NIIs) are large net-worth investors. We discuss the investor categories in detail in Section 3.
} 
The transparency in the IPO mechanism, coupled with the fact that different investor categories participate for separate quotas of shares may have important implications for investors' participation, IPO pricing and returns. First, information available from the transparent mechanism should influence both investors' participation and the timing of that participation. Second, prior research suggests that the nature and timing of investors' participation influences offer prices (Cornelli and Goldreich, 2003; Degeorge et al., 2010). Hence, transparency in the mechanism and the nature of investors' participation that it brings should exert influence on IPO pricing. Third, since informed and uninformed investors participate for a different quota of shares on offer, uninformed investors should be able to avoid the winners' curse documented in prior research (Koh and Walter, 1989; Keloharju, 1993; Amihud et al., 2003).

Using a sample of 306 IPOs issued during the 2001-2010 period, the paper investigates three main issues. First, since information on the participation of institutional investors, considered as informed, is publicly available during the offer period, we examine how this information influences the participation of retail investors. While prior studies on investors' participation have used the timing (early or late) and the type of bid (market order or price limit bids) to examine the informativeness of the bids (Cornelli and Goldreich, 2003; Jenkinson and Jones, 2004), our study examines the informativeness of bids by investor type. Second, we examine the influence of retail investors' participation on IPO pricing. We do so after controlling for a number of market, offer and firm characteristics, including the participation of institutional investors. While Derrien (2005) examines retail investors' influence in setting IPO prices, the study does not control for the participation of institutional investors. Third, since retail investors participate and are allocated shares from a separate tranche of shares on offer, we also examine whether this setting allows retail investors to earn positive returns after adjusting for allocation. 
Prior research has examined returns earned by retail investors in a setting where they compete with informed institutional investors (Koh and Walter, 1989; Keloharju, 1993; Amihud et al., 2003).

We report several interesting findings. First, we find that aggregate demand is concentrated at either one or two points of the offer price range. In most of the IPOs, investor demand is exclusively concentrated at the upper bound of the offer price range. In others, it is concentrated at the lower bound with very little investor participation in between the two price points. Furthermore, we find that a large number of investors, both institutional and retail, submit only strike bids which is in contrast to the findings reported in previous research conducted in a less transparent setting (Cornelli and Goldreich, 2003; Degeorge et al., 2010; Kandel et al., 1999).

Second, we provide new insights into the participation of institutional and retail investor in IPOs. We find that the transparency in the mechanism induces heavy investors' participation in the later stages of the offer period, which is particularly strong for retail investors. Importantly, we find that the early participation of institutional investors significantly influences the extent of retail investors' participation. The participation of institutional investors, on the other hand, appears to be influenced by recent market returns, size of the offer and underwriters' reputation.

Third, analysis of offer prices shows that favourable retail investors' demand contributes significantly to high offer prices. While institutional investors' demand also influences offer prices positively, the economic significance of retail investors' demand appears to be higher. Since recent market return is also positively associated with offer prices, our analysis suggests that underwriters exploit market sentiment by setting high IPO prices in the presence of favourable uninformed demand and positive general market conditions. 
Finally, we examine the allocation adjusted initial returns for retail investors. We find that even in a setting where retail investors do not compete with institutional investors and where information on institutional investors' participation is publicly available, retail investors are no more likely to make positive returns. Aggressive bidding by overconfident uninformed investors in IPOs with poor institutional demand results in a negatively skewed distribution of allocation weighted returns. We, however, find that retail investors can earn significant positive allocation adjusted returns by conditioning their subscription in only those IPOs with greater than average institutional investors' demand.

The paper makes a number of important contributions. First, to the best of our knowledge this is the first paper which examines a number of issues in an IPO mechanism which is far more transparent than those used in other IPO markets. While some prior studies on Indian IPOs have examined the effect of regulatory changes on underpricing (Bubna and Prabhala, 2010) and the influence of mandatory IPO grading (Deb and Marisetty, 2010), our paper examines the extent of investors' participation and IPO pricing in significant detail. The paper also highlights key implications of a transparent IPO mechanism for investors' participation and IPO pricing which should also be useful to market participants and regulators in less transparent markets.

Second, our study also enriches the existing evidence on the participation of institutional and retail investors. Consistent with prior evidence, we find that institutional investors participate on the basis of the information they possess, while retail investors behave as sentiment or noisy traders (Aggarwal et al., 2002; Chiang et al., 2010; Degeorge et al., 2010). More tellingly, through our analysis of evolution of demand, we provide evidence on the timing of the participation of the different investor categories. Further, while prior studies on the timing of 
investors' participation have used aggregate investor demand (Cornelli and Goldreich, 2003; Jenkinson and Jones, 2004), we consider the timing of investors' participation by investor type.

Third, our paper also adds to the literature that examines the determinants of retail investors' participation in IPOs. We complement Chiang et al. (2010), who show that retail investors are influenced by returns on recent IPOs, and provide evidence that information on the participation of institutional investors also influences the participation of retail investors. Finally, our paper also extends the findings on returns earned by retail investors in IPO investment (Koh and Walter, 1989; Keloharju, 1993; Amihud et al., 2003). Our examination of allocation weighted initial returns brings to light the irrational behaviour of retail investors even in a setting where information on the participation of informed institutional investors is publicly available.

The remainder of the paper is organized as follows. Section 2 discusses the related literature. Section 3 presents some of the key institutional features of the Indian IPO market. Section 4 develops the hypotheses. Section 5 presents the IPO sample and the descriptive statistics. Section 6 presents the empirical evidence. Section 7 reports concluding remarks.

\section{Related literature}

\subsection{Investors participation in IPOs}

There is a significant body of theoretical literature that discusses investors' participation and information production in the context of IPO mechanisms. Benveniste and Wilhelm (1990), for instance, model an optimal IPO mechanism and argue that the pricing and allocation discretion afforded by the bookbuilding and two-stage marketing mechanism helps underwriters extract valuable information from informed investors. Sherman (2000) models how bookbuilding creates regular groups of investors and shows how bookbuilding helps in both lowering average 
underpricing and providing returns to investors so that they could engage in information gathering and reporting. Biais and Faugeron-Crouzet (2002) and Biais et al., (2002) show that Offre à Prix Minimal, a modified auction mechanism used in France, exhibits informationextraction properties similar to bookbuilding.

Using proprietary IPO data, Cornelli and Goldreich (2003) and Jenkinson and Jones (2004) provide mixed evidence on information production in bookbuilding IPOs. Cornelli and Goldreich (2003) find that more informative bids (bids which are submitted early and/or price limit bids) not only influence the offer price but also IPO allocations, evidence that is consistent with the information revelation theories. Jenkinson and Jones (2004), on the other hand, report that bids submitted by investors are not informative for pricing purposes and instead find that the most important determinant of IPO allocation is whether the investor is viewed as a long term holder of the stock. In a survey of a large number of institutional investors participating in bookbuilding IPOs, Jenkinson and Jones (2009) find evidence that is inconsistent with the information revelation theory. They find that while only one half of the investors actually develops valuation models, the rest consider brokering relationships as the most important source for receiving favourable IPO allocations.

In the context of auction IPOs, Kandel et al. (1999) examine demand schedules of Israeli IPOs and find highly informative and elastic demand curves. Lin et al. (2007) examine the relative ability of institutional investors in Tawainese auction IPOs and find that institutional investors are better informed about IPO value and, compared to retail investors, bid higher in IPOs with high initial returns. Chiang et al. (2010) also examine Taiwanese IPO auction data and find that a higher number of institutional investors or larger institutional bids are positively associated with higher initial returns. They argue that while the participation of institutional investors is on the 
basis of their information about the value of the issue, the participation of retail investors is influenced by the returns on recent IPOs, consistent with evidence of return chasing behaviour. Degeorge et al. (2010) analyse US auction IPOs and find that issuers and underwriters extract useful pricing information from investor bids in setting the offer price. They find elastic demand curves for institutional investors, an indication that institutional investors produce and reveal information. Further, they report that underwriters exercise significant discretion in pricing by setting the offer price below the market clearing price in a large number of IPOs.

\subsection{Pricing of IPOs}

Theories on information revelation and the principal-agent model discuss the setting of IPO offer prices by focusing on the role of underwriters. While the information revelation theories focus on the role of underwriters in eliciting useful information in setting IPO prices, theories on the principal-agent model focus on price setting by highlighting the potential for agency problems between the underwriter and the issuing firm. In the context of information revelation theories, which assumes that some investors are well informed about the value of the offer, Benveniste and Spindt (1989) posit that underwriters price IPOs in order to reward investors who reveal valuable information during the offer period. The partial adjustment phenomenon posited by Hanley (1993) is also consistent with information revelation theories as price revisions over the bookbuilding period and first day initial returns are positively related.

The principal-agent model which assumes that underwriters are well informed about the value of the offer, posits that underwriters face a trade-off in setting offer prices between high IPO prices leading to higher commission and high underpricing leading to reduced selling efforts. Baron and Holmstrom (1980) and Baron (1982) examine the conflict of interest arising from the unobservability of the underwriter's marketing effort and argue that underwriters exploit their 
superior knowledge of the market and underprice issues to minimize marketing effort and to ingratiate themselves with buy-side clients. Since the burst of the internet bubble, there has been a strong interest in principal-agent explanations of IPO pricing with evidence of spinning (Hao, 2007) and biased IPO allocations (Reuter, 2006; Ritter and Zhang, 2007).

There are several other studies which have also examined IPO pricing. Rock (1986), for instance, argues that firms price (underprice) IPOs in order to attract the participation of uninformed investors. Loughran and Ritter (2002) present prospect theory in explaining IPO pricing and suggest that issuers care less about large underpricing as they not only consider the shares they sell, but also those they retain which benefit from high underpricing. Using a large sample of US IPOs, Purnanandam and Swaminathan (2004) find that IPOs are highly overpriced compared to their industry peers. They also find that the high priced IPOs are positively associated with high initial returns but negatively associated with long term risk adjusted returns. Using a sample of French IPOs, Derrien (2005) finds that the favourable demand of retail investors has a significant positive influence on high IPO prices and that such favourable demand leads to high initial returns but poor long term performance. Further, he finds that the favourable demand of retail investors is only partially incorporated into IPO offer prices.

\section{Institutional features of Indian IPO market}

\subsection{Transparency in IPO selling mechanisms in India}

One of the unique features of the Indian IPO market is the transparency in the offer process. Throughout the offer period, information on the participation of various investor categories is publicly available on a real time basis on stock exchange websites where the IPO is to be listed. The transparency in the mechanism allows investors to observe two important pieces of 
information. First, investors can observe the cumulative aggregate investors' demand at different price points of the initial price range. Second, investors can also observe the subscription (demand multiple) of different investor categories for their respective portions of the offer. This information becomes available because investors are required to bid with one of the syndicate members who, in turn, initiates the order in the electronic book. The electronic book is connected to the central bookbuilding software managed by the stock exchange. ${ }^{3}$ Appendix A shows an example of the information displayed during the offer period on the stock exchange website. Information on subscription by various investor categories is also widely reported in all major print and electronic news media throughout the offer period.

Regulations relating to Indian primary markets have undergone significant changes over the last 10 years. Prior to the establishment of the Securities and Exchange Board of India (SEBI) as the regulatory authority in 1992, security issuance in India was governed by the Capital Issues Act, 1947 and was administered by the office of the Controller of Capital Issues (CCI). Prior to 1999, fixed price was the only mechanism available to IPO issuers. A modified version of the US style bookbuilding mechanism was first introduced in 1999 and quickly became the preferred IPO mechanism. The bookbuilding mechanism allowed underwriters to exercise discretion in setting IPO prices and in allocation of shares in the Qualified Institutional Investor (QIB) category.

However, in late 2005, in response to some irregularities in the market ${ }^{4}$, SEBI introduced a number of changes in the bookbuilding mechanism. The change in the regulation prohibited

\footnotetext{
${ }^{3}$ Source: Bombay Stock Exchange (BSE) website; www.bseindia.com

${ }^{4}$ In 2004 and 2005, irregularities were discovered in the allocation of shares for a number of IPOs including the IPOs of Yes Bank, Piramyd Retail and Bombay Rayong Fashion. SEBI unearthed a large scale multiple application case in Yes Bank IPO and banned 13 investors from trading in the bank's shares with immediate effect.
} 
underwriters from exercising allocation discretion in the QIB category ${ }^{5}$. Thus, the current Indian IPO mechanism, while still referred to as bookbuilding, in practice appears more like a nondiscriminatory or uniform type of auction mechanism, similar to the one used by WR Hambrecht in the US.

\subsection{Investor categories}

In Indian IPOs, a separate quota of shares is made available for different investor categories. Primarily there are three investor categories for whom shares are reserved and then allocated: Retail Individual Investors (RIIs), Non-Institutional Investors (NIIs) and Qualified Institutional Buyers (QIBs) ${ }^{6}$. QIBs are generally allocated about $50 \%$ of the shares on offer, while about $15 \%$ and $35 \%$ of the shares are allocated to NIIs and RIIs respectively. The current IPO guidelines define RIIs as those whose total bidding value does not exceed INR 100,000 ${ }^{7}$. This limit was initially set at INR 25,000 in 1995 and has been gradually increased over the years. QIBs are large institutional investors such as commercial banks, mutual funds, venture capital funds, and insurance companies who are registered with SEBI. Appendix B presents a list of QIBs. All other investors whose bidding value exceeds the RIIs' threshold but are not registered as QIBs are considered to be NIIs.

Investors are allowed to submit orders at prices in increments of 1 INR within the offer price range. The regulation requires the offer price range to be within $20 \%$ of the floor price. While RIIs have the option to submit strike bids (referred to as cut-off bids), both QIBs and NIIs are allowed to submit only price limit bids. However, since the original offer price range has historically never been revised upwards, submitting a bid at the upper end of the price range is

\footnotetext{
${ }^{5}$ In addition, issues after November 2005 are also required to allocate 5\% of QIB shares to domestic mutual funds.

${ }^{6}$ In a number of IPOs, employees are also reserved a certain a portion of the total shares on offer.

${ }^{7}$ Equivalent to US\$2,500 at the average exchange rate.
} 
effectively placing a strike bid. Investors are allowed to revise their bids for both price and quantity prior to the end of the offer period. While the offer is generally open for five days, the offer period is extended for a further three days when there is a revision in the original price range.

While RIIs and NIIs are required to deposit the entire bidding amount at the time of submitting the bids, institutional investors are required to deposit only $10 \%$ of the bidding amount ${ }^{8}$. At the end of the offer period, the underwriter aggregates the demand and chooses an offer price. All orders at or above the offer price are filled on a pro rata basis while orders below the offer price are left unfilled and refunded. Indian IPO regulations allow the underwriter to re-allocate shares from the unsubscribed investor category to oversubscribed categories. Thus, if the RIIs' portion is undersubscribed, the unsubscribed portion is re-allocated to QIBs and NIIs. The allocation of IPO shares to different investor groups serves well for the price discovery process. Because different investor categories have their own pre-determined quota of shares, informed investors can bid on the basis of their own private information without worrying about disruption in the price discovery process by less informed investors.

\section{Hypotheses}

\subsection{Retail investors' participation}

A number of theoretical models, including Rock's (1986) winners' curse and Benveniste and Spindt's (1989) information acquisition model, assume that some investors are more informed than others. The segregation of informed and uninformed investor categories is at the heart of their models which have stimulated research that examines whether differences exist in how

\footnotetext{
${ }^{8}$ Retail investors bidding at the cut-off price are required to deposit in the Escrow Account the bid amount based on the upper bound of the price range.
} 
different investor categories participate in IPOs. The evidence available hitherto strongly supports the view that some investors are more informed than others. Prior studies have shown that large institutions, a proxy for informed investors, participate highly and hence receive a larger percentage of shares in well performing IPOs issued in both bookbuilding and auction mechanisms (Aggarwal et al., 2002; Chiang et al., 2010; Degeorge et al., 2010; Hanley and Wilhelm, 1995; Koh and Walter, 1989).

As discussed earlier, the transparency of the IPO mechanism allows investors to observe prior demand of IPO shares. Since investors can observe the demand of other investors, it is likely that some less informed investors may simply follow those who participated earlier. In fact, prior literature has shown evidence of herding by both institutional and retail investors (Lakonishok et al., 1992; Shleifer and Summers, 1990). We, therefore, posit the following hypothesis on retail investors' participation in Indian IPOs:

$\boldsymbol{H}_{1}$ : Uninformed retail investors will submit their bids for shares late in the offer period only after observing the demand by early bidders.

\subsection{Pricing}

The information revelation theories argue that an IPO is priced to reward investors who reveal useful information during the IPO process. Benveniste and Spindt (1989) develop an information acquisition model where underwriters underprice the offer as a reward to informed investors who provide valuable information about the intrinsic value of the firm. Cornelli and Goldreich (2003) provide empirical evidence of the information acquisition hypothesis and show that investors submitting early bids, as well as bids that carry information, are rewarded by underwriters. They 
further show that price limit bids have a significant influence on the final IPO price determined by the underwriters.

While information revelation theories were developed on the US style bookbuilding mechanism, Degeorge et al. (2010) show that information revealed during an auction is equally useful in setting IPO prices. They report highly elastic demand curves and find that the demand of institutional investors has a significant influence on the offer price. Information available from the transparent Indian IPO mechanism allows us to observe informative bids for a large sample of IPOs. Hence, we posit the following hypothesis:

$\boldsymbol{H}_{2}$ : Informative bids (price limit bids) will have a positive and significant influence on the IPO offer price.

Further, Derrien (2005) models the IPO offer price and shows that the final price depends on the intrinsic value of the firm as revealed by informed investors and on the sentiment of the noise traders (individual investors). Using a sample of French IPOs, in which a fraction of the shares is reserved for retail investors, the study shows that favourable sentiments of the retail investors are positively associated with higher offer price. The setting of the Indian IPO market bears a strong resemblance to Derrien's (2005) model as a certain portion of total IPO shares is reserved for individual investors. Hence, following Derrien (2005), we formulate the following hypothesis:

$\mathrm{H}_{3}:$ The IPO price will be positively related to the demand of uninformed retail investors.

\subsection{Allocation weighted returns for retail investors}

Rock (1986) argues that because of adverse selection, retail investors, on average, are only likely to make returns equal to the risk-free rate of return on their IPO investments. This is because informed investors participate well only in underpriced IPOs and hence uninformed investors 
receive a greater proportion of shares in overpriced IPOs. Using data from Singaporean IPOs, Koh and Walter (1989) find evidence consistent with Rock's prediction. They find that, after adjusting for allocation, the IPO return is not significantly different from zero. Using data from UK IPOs, Levis (1990) finds that the allocation weighted average returns are positive and significant. Keloharju (1993) finds that after adjusting for allocation bias, unadjusted average returns reduce significantly, evidence consistent with Rock's (1986) hypothesis. Amihud et al. (2003) analyse Israeli IPOs and find that uninformed investors earn negative allocation weighted initial returns. They further show that uninformed investors can reduce their loss in IPO investment by conditioning their participation on publicly available information.

Since, in the case of Indian IPOs, a separate quota of shares is reserved for retail investors, they do not have to compete directly with informed institutional investors. This eliminates the problem of being crowded out by informed investors in good offerings. Further, underwriters for Indian IPOs do not have allocation discretion as retail investors receive allocation on a pro rata basis. Since information concerning the participation of informed institutional investors is publicly available at the time of the offer, it is likely that the zero or negative allocation weighted initial returns documented in prior studies may not occur in the case of Indian IPOs. Hence, in the context of Indian IPOs, we posit the following hypothesis on allocation weighted initial returns for retail investors:

$H_{4}$ : Retail uninformed investors are more likely to earn positive allocation weighted initial returns. 


\section{Sample data and descriptive statistics}

\subsection{Sample data}

Our sample comprises of 306 bookbuilding and auction IPOs listed on the Bombay Stock Exchange (BSE) and/or the National Stock Exchange (NSE) of India over a 10 year period from January 2001 to December 2010. We exclude large privatization IPOs of utilities and banks as they are not representative of average firms. We collect data on firm and IPO characteristics from the IPO prospectus. We obtain market data from the BSE/NSE website. We use unadjusted prices to calculate initial returns on IPOs and the BSE Sensex index as the market index to calculate market adjusted initial returns. Data on IPO demand is obtained from the BSE/NSE and some other finance portals including the website of ICICI Bank (one of the leading commercial and investment banks in India), Money Control (considered to be the top finance portal in India ${ }^{9}$ ) and Chittorgarh (considered to be India's primary IPO investment portal ${ }^{10}$ ).

\subsection{Descriptive statistics}

\subsubsection{IPO sample}

In this section we present descriptive statistics of our sample of IPOs. Table 1 presents descriptive statistics by year. We find that the mean (median) age of the firm at the time of the IPOs is about 14.19 (12.21) years. The mean (median) total assets and gross proceeds of the overall sample are INR 6,874 (1,945) million and INR 3,535 $(1,128)$ million respectively ${ }^{11}$. The mean (median) leverage (total liabilities/total assets) of the IPO firm is $0.56(0.60)$. The mean (median) raw first day return (interchangeably used for underpricing) for the period is $22 \%$

\footnotetext{
${ }^{9}$ WwW.moneycontrol.com

${ }^{10}$ www.chittorgarh.com

11 US\$ is roughly equivalent to INR 45.
} 
(13\%). This is much higher than those reported by studies using IPO data from the US and other developed markets, but is similar to initial returns reported in other emerging markets.

\section{$<<$ Insert Table 1 here $>>$}

To account for changes in the market conditions from the time of the offer to the listing date, we calculate market adjusted returns ${ }^{12}$. The mean (median) market adjusted first day return over our sample period is $21 \%$ (10\%) while the one month market adjusted mean (median) initial return is $18 \%(8 \%)$. Of particular interest is the number of IPOs with a negative return on the first day of trading. More than a third of the total IPOs (111 of 306) have negative returns on the first day of trading suggesting that the IPOs are not only overpriced but also that the underwriters' activity, in the after-market to support the prices of the IPOs they manage, is very limited. The overall demand for IPOs is captured by the total demand multiple. The mean (median) overall total demand multiple is 20.51 (8.08) times which suggests that Indian IPOs are well subscribed.

Following Cornelli and Goldreich (2003) (CG hereafter), we also present the average offer price and the quantity adjusted average limit price, both normalized to the offer price range. We find that both average offer price and average limit price in our sample is significantly higher than those reported by CG. CG report a mean (median) normalized offer price and average limit price of $0.51(0.67)$ and $0.49(0.49)$ respectively. The mean (median) normalized offer price and average limit price of our sample are $0.80(1.00)$ and $0.22(0.21)$ respectively. Overall, a larger portion of our IPOs are priced at the upper end of the price range and most of the price limit bids are received at the lower end of the demand schedule.

\footnotetext{
${ }^{12}$ On average Indian IPOs are listed 21 days from the day the offer is open for bidding.
} 


\section{$<$ Insert Table 2 here $>>$}

\subsubsection{Investors' aggregate demand}

Table 2 presents descriptive statistics of aggregate IPO demand. We present aggregate investor demand at five different points of the initial offer price range: demand at the lower bound, at the mid-point, below the mid-point, above the mid-point and at the upper bound of the original offer price range. For demand at below and above the mid-point we aggregate all demand between these points. As shown in Panel A of Table 2, on average about $87 \%$ of all investors submit a strike bid. If we consider investors' demand for shares at the lower end of the demand curve, the total investors' demand for shares at these two points accounts for about $95 \%$ of overall demand. Investors' demand at all other points of the offer price range is almost negligible. Further, the demand for shares does not differ significantly by allocation mechanisms. Both bookbuilding and auction IPOs exhibit similar participation by investors. Thus, the change in regulation in late 2005, which prohibited discriminatory allocations to institutional investors, does not appear to have made any significant difference to the way investors participate in IPO offerings. Our results are not contrary to those reported by Bubna and Prabhala (2010) who find that underwriters exercise significant discretion in allocations ${ }^{13}$. While the allocation pattern may have been different in bookbuilding mechanism, our results suggest that the pattern of investors' participation in bookbuilding does not appear to be different from the pattern seen in auction IPOs.

The number of investors who submit a strike bid in our sample of IPOs is similar to the number reported by $\mathrm{CG}$ for their sample of European IPOs. We investigate this further by examining the

\footnotetext{
${ }^{13}$ It is important to note that Bubna and Prabhala (2010) use a difference-in-difference approach to study the implication of a change in allocation rules on underpricing, in which they control for oversubscription, and hence their results are not driven by aggregate demand.
} 
proportion of IPOs in which investors submit a strike bid. Panel B of Table 2 documents the percentage of investors who submit strike bids. As shown in the Table, we find that strike bids account for more than $99 \%$ of all bids in 111 IPOs (40\% of the total sample). Hence, the fraction of IPOs that do not have price limit bids in our sample is much higher than the 5\% (2 out of 37 ) reported in the CG sample. Further, we find that strike bids account for more than $90 \%$ of all bids submitted in 201 IPOs (71\% of the total sample). Results are similar for bookbuilding and auction IPOs. Thus, the overall percentage of price limit bids that we document in our sample is not as a result of having a sizeable portion of price limit bids as in CG but rather, it is on account of having a few IPOs in which investors bid disproportionately at the lower bound of the demand schedule. Further, the low normalized quantity adjusted average limit price of our IPO sample, which is only 0.22 compared to 0.49 in CG, also suggests that price limit bids are mostly at the lower end of the demand schedule.

\section{Empirical results}

\subsection{Investor participation}

In this section we analyse the evolution of investors' demand over time and examine the determinants of investor participation in IPOs. The IPO offer is generally open for subscription for five days ${ }^{14}$. For this part of our analysis we use a smaller data set of 195 auction IPOs for which we have complete data on investors' demand over time.

In panel A of Table 3, we show the subscription pattern of different investor categories over time. We examine demand multiple over the five day auction period. While day 0 refers to the final day of bidding period, day 1 refers to the penultimate day of bidding and so forth. Prior

\footnotetext{
${ }^{14}$ In case of revision in the offer price range, the offer period is extended for another three days. Very few IPOs have revised their price range in our IPO sample.
} 
research suggests that bids submitted earlier are more informative as these are likely to be submitted by informed investors. Results from Panel A indicate that large institutional investors (QIBs) are more likely to bid early than both retail (RIIs) and non-institutional investors (NIIs). We find that in 69 of the 195 IPOs, the QIB category is fully subscribed by the end of the third day of auction period. The corresponding numbers for NII and RII investors are 59 and 20 respectively. In fact, the bulk of retail investors' participation appears to occur predominantly on the final day of the bidding period. The retail portion of the offer is fully subscribed in only 46 of the 195 IPOs by the end of the penultimate day. Initial analysis of demand over time shows that while institutional investors, most likely because of their informational advantage, appear to be less interested in the demand of other investors and submit their bids early, the less informed retail investors appear to submit their bids only after observing the demand of the more informed investors.

\section{<<Insert Table 3 here $>>$}

To analyse whether other investors, and in particular retail investors, follow QIBs or have their own bidding strategies, we classify IPOs into two categories: those with strong and weak institutional demand. We consider IPOs in which the QIBs' portion is fully subscribed by the end

of the $3^{\text {rd }}$ day (Day 2 in Table 3) as IPOs with strong demand (Rocholl, 2009) and the rest as IPOs with weak demand. Accordingly, we have 69 IPOs with strong and 126 with weak institutional demand. Results from panel B of Table 3 show that a disproportionately large amount of bidding occurs on the final day across all investor categories. Even in IPOs where the offer is fully subscribed by the penultimate day, we find heavy participation from all investor categories on the final day of the auction period. It appears that for IPOs with strong demand, 
both NIIs and RIIs essentially follow QIBs. The median strong IPO is subscribed almost five times by QIBs by the penultimate day when the median cumulative demand for NIIs and RIIs is just 0.68 and 0.52 respectively. However, the final day demand is significantly high, not only for NIIs and RIIs but for QIBs as well. This suggests that not only do NIIs and RIIs follow QIBs, but some less informed QIBs also appear to follow well informed investors. The finding is consistent with Jenkinson and Jones (2009) who report that only one half of institutional investors develop their own valuation models while investing in IPOs.

Interestingly, in the case of IPOs with weak institutional demand, we find that NIIs are more likely to fully subscribe their portion of the shares prior to both QIBs and RIIs. In these weak offerings, NIIs fully subscribe 36 IPOs by the end of the $3^{\text {rd }}$ day (Day 2 in our analysis) when not even a single IPO is fully subscribed by QIBs. By the end of the penultimate day of bidding, the median demand multiple of NIIs (1.001) is significantly higher than the demand multiples of both QIBs (0.64) and RIIs (0.32) with p-values at less than 5\% significance level. The difference in NIIs' subscription compared to other investor categories persists even on the final day of bidding. RIIs appear to follow QIBs who participate early in strong IPOs.

We undertake a multivariate regression analysis to explain both the early participation of QIBs and NIIs and the late surge in the participation of RIIs during the offer period. Our choice of independent variables is guided by prior research (Derrien, 2005; Rocholl, 2009) and we include a number of control variables including the size of the issue (LnGpcds, log of gross proceeds), recent market return $(M k t 3 M w)$, recent market volatility $(M k t V o l)$, one plus log of age of the firm (LnAge) and an industry dummy (HiTech) which takes the value of 1 for IPOs in the hi-tech industry (information technology and bio-technology) and zero otherwise. $M k t 3 M w$ is the weighted average of the buy-and-hold returns on the BSE Sensex index in the three months 
before the IPO date where weights are three for the recent month, two for the next and one for the third month before the offering. MktVol is the standard deviation of the index returns one month prior to the offer issue date.

We also include underwriter reputation (LbmRep) via a dummy variable as it is likely that more reputed underwriters will attract large institutional investors compared to less reputed ones. We define reputed underwriters based on the value of IPOs managed by them during the sample period $^{15}$. For explaining RIIs' participation, we also include early demand of IPO shares by QIB $\left.(\operatorname{LnDmtlQIB})_{1}\right)$ investors. We define early demand as the log of one plus the cumulative demand multiple at the end of the penultimate day of the offer period. For explaining the early NIIs' demand, we also include the log of one plus the cumulative demand multiple of QIBs at the end of the third day $\left(\mathrm{LnDmtlQIB}_{2}\right)$. The result of the regression analysis is shown in Table 4 where the reported t-statistics are adjusted for heteroskedasticity. All our regressions also control for the year fixed effects. The dependent variable in regressions (1) and (2) is the log of one plus the cumulative demand multiple for QIBs $\left(\operatorname{LnDmtlQIB}_{l}\right)$ and NIIs $\left(\operatorname{LnDmtlNII}_{l}\right)$ at the end of the penultimate day, while the dependent variable in regressions (3) to (5) is the log of one plus the

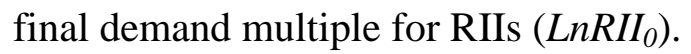

\section{$<<$ Insert Table 4 here $>>$}

Results from regression (1) suggest that the early participation of QIBs is significantly higher in larger IPOs. Further, the early participation of QIBs is also likely to be higher in periods following high recent market returns and in IPOs managed by reputed underwriters. Regression (2) shows that the early participation of QIBs has a positive and significant influence on the

\footnotetext{
${ }^{15}$ We categorize underwriters as reputed who have managed at least 10,000 million INR during the sample period. This results in having 15 reputed and 42 less reputed underwriters. Alternatively, we also look at the top five underwriters every year during 2005-2010. Our classification of underwriters qualitatively remains the same.
} 
participation of NIIs. The negative coefficient on the underwriter's reputation variable, along with insignificant coefficients on recent market returns, volatility and the size of the offering, suggests that NIIs tend to invest in an unpredictable manner and appear to be less well informed.

Regression (3) examines the determinants of RIIs' participation for the overall sample ${ }^{16}$. We find that the coefficient on early QIB $\left(\operatorname{LnDmtlQIB}_{l}\right)$ demand is both positive and significant which is consistent with our hypothesis. In fact the early participation of QIBs explains almost one third of the variation in RIIs' participation. Further, when we include the size of the offer, the two variables explain almost fifty percent of the variation in RII participation. In regressions (4) and (5) we segregate the IPOs into two categories: those with strong and weak demand. As discussed earlier, we consider IPOs with strong demand as those which are fully subscribed by the QIBs two days prior to the close of the offer period. In both regressions (4) and (5) the coefficient on early QIB participation remains positive and significant. Thus, the influence of the participation of QIBs on RIIs is not only limited to strong IPOs, it is equally influential in the case of weak IPOs. Thus our result suggests that RIIs appear to follow informed investors when information on the participation of informed investors is available. The coefficient on LnGpcds is negatively related to RII participation which is most likely to be a reflection of the size effect as our dependent variable, the demand multiple, is likely to be higher for smaller issues than for larger issues. Our regression results also show that while recent market returns have a positive influence on the participation of retail investors, market volatility has a negative impact on their participation.

\footnotetext{
${ }^{16}$ Since RIIs mostly participate on the final day of the bidding period, we use the final day demand as the dependent variable. Alternatively, we also use the net demand on the final day as the dependent variable. Our results remain qualitatively similar.
} 


\subsection{The pricing of IPOs}

In this section we analyse the determinants of IPO offer price by conducting a multivariate regression analysis with the normalized issue price (NorPrice) (to the price range) as in CG, as our dependent variable. Results are shown in Table 5 where the reported t-statistics are adjusted for heteroskedasticity. All our regressions also control for year fixed effects. In regression (1) we regress the normalized IPO price on the average limit price (AvLimitPr). Consistent with CG, we find that the coefficient on the average limit price is positive and statistically significant, suggesting that the limit prices contained in the demand schedule do influence the final offer price. However, as discussed earlier, the significant average limit price is due to the high demand at the lower bound of the price range in some IPOs. Hence, in regression (2) we re-run the analysis with the log of one plus the total demand multiple ( $L n D m t l)$. We find that $L n D m t l$ has a positive and statistically significant impact on the normalized price. In fact, the total demand multiple explains more of the variation in the normalized price than the average limit price. In regression (3) we include both average limit price and total demand multiple and find that the economic significance of total demand multiple is almost three times that of the average limit price. Although a large number of IPOs do not have price limit bids, for IPOs in which such bids occur, they are highly significant in determining the offer price and hence the finding is consistent with hypothesis 2 .

\section{$<<$ Insert Table 5 here $>>$}

In regression (4) we include the elasticity of demand observed at the average price limit. The coefficient on the elasticity of demand is negative and statistically significant, suggesting that higher elasticity is associated with more conservative pricing. Since the elasticity of demand at the limit price is mostly concentrated at the lower bound of the demand curve, it is only natural 
that the higher elasticity leads to a relatively lower normalized offer price. In regression (5) we include a number of control variables including the demand multiple of the three investor categories (QIB, LnDmtlQIB, NII, LnDmtlNII and RII, LnDmtlRII), underwriter reputation (LbmRep), log of gross proceeds (LnGpcds), a dummy industry variable (HiTech) that takes the value of 1 for hi-tech industries and 0 otherwise, recent market return $(M k t 3 M w)$, recent market volatility (MktVol) and a dummy variable for allocation mechanism (Mechanism) which takes the value of 1 for bookbuilding IPOs and 0 otherwise.

As shown in regression (5), the coefficients on both the QIB and RII demand multiples are positive and highly significant. This suggests that demand from both informed as well as uninformed sentiment investors have an influence on IPO prices. More importantly, our finding on the influence of RIIs' demand on offer price is consistent with hypothesis 3 even when we control for QIBs' demand. Moreover, the size of the two coefficients suggests that the influence of RII demand is higher in setting high offer prices than the QIB demand. Further, recent market returns have a significant and positive influence on the offer price. Hence, underwriters appear to exploit market sentiments by setting high IPO offer prices in times of favourable demand from uninformed investors and favourable general market conditions.

Our regression results also appear to suggest that reputed underwriters are more likely to set a more conservative price than less reputed ones. The mechanism variable is insignificant, suggesting that there is little difference in the way prices are set in the two allocation mechanisms. Similarly, coefficients for size of the issue, age of the firm and hi-tech IPOs are insignificant. In regression (6), we replicate model (5) by leaving out the average limit price and elasticity variables to run the regression on the entire sample of 306 IPOs. Overall, our results 
remain the same although the explanatory power of the model drops as a consequence of leaving out these two important variables.

\subsection{Allocation weighted initial returns ${ }^{17}$}

Next, we examine the allocation weighted initial returns for retail investors. Since investors in each category participate and receive an allocation from their respective quota of shares, it will be interesting to observe how retail investors fare after taking into account the overall demand of the issue. The unique feature of the Indian IPOs means that while retail investors may receive higher allocations in poor IPOs, they will not be crowded out by informed institutional investors in a good quality offering ${ }^{18}$. For this part of our analysis we follow Amihud et al. (2003) and assume that retail investors subscribe to a fixed amount in each and every IPO. Since retail investors are required to deposit the total amount that they bid for at the time of bidding, their funds are tied up on average for about 36 days. On average, IPO firms are listed 21 days after the closing of the issue and IPO firms are mandated to refund unsuccessful bidders within 15 days of the listing date. For the purpose of calculating the interest expense, we use the State Bank of India's advance rate prevailing for each year in our sample period, which is available from the Reserve Bank of India Fact Book. The average interest for 36 days during the period of our study is $1.09 \%$.

\section{$<<$ Insert Table 6 here $>>$}

\footnotetext{
${ }^{17}$ We thank the anonymous referee for suggesting to us that we examine the allocation weighted returns for retail investors.

${ }^{18}$ Since regulation allows underwriters to re-allocate unsubscribed shares of QIB and NII investor categories to RIIs, RII investors may end up receiving higher allocations in offerings which are undersubscribed by other investor categories.
} 
In Table 6 we present the allocation weighted market adjusted initial returns for retail investors after the first day $\left(A W M I R_{1}\right)$, first week $\left(A W M I R_{7}\right)$ and first month $\left(A W M I R_{30}\right)$ of listing ${ }^{19}$. We use returns on the BSE Sensex to calculate the market adjusted returns. Results show that while the mean allocation weighted initial returns for retail investors is not significantly different from zero for the first day and first week returns, it is negative and statistically significant for the first month returns. Hence, our results are not consistent with hypothesis 4. Thus, the negative allocation weighted returns documented by Amihud et al. (2003) exist, even in a setting where retail investors do not have to compete with informed institutional investors. Figure 1 presents the histogram of $A W M I R_{30}$ which shows that distribution of allocation weighted return is negatively skewed, confirming higher allocation in IPOs with negative initial returns.

\section{$<<$ Insert Figure 1 here $>>$}

Figure 2 presents the relationship between first month market adjusted initial returns and allocation weighted market adjusted initial returns $\left(A W M I R_{30}\right)$. As shown in the figure, most observations lie below the $45^{\circ}$ line which means that the demand for shares by retail investors is much higher than the number of shares which are offered to them. While there are very few observations above the $45^{\circ}$ line when returns are positive, there are a large number of observations below the $45^{\circ}$ line when returns are negative. It is perhaps due to the transparency in the IPO mechanism, which allows retail investors to observe the participation of informed institutional investors, that the allocation weighted returns are closer to zero in most IPOs with positive initial returns. More importantly, in IPOs with negative initial returns, the allocation

\footnotetext{
${ }^{19}$ We also calculate allocation weighted returns based on raw initial returns but do not report these as the results are similar.
} 
weighted returns are extremely negative, suggesting that these are caused by a smaller number of overconfident retail investors (Amihud et al., 2003) who participate in such offerings.

\section{<<Insert Figure 2 here〉>}

Following Amihud et al. (2003) we also analyse retail investors' allocation weighted initial returns conditional on information that is available to retail investors at the time of bidding. For this purpose we estimate a regression model on the $A W M I R_{j}$ with recent market returns $(M k t 3 M w)$, market volatility ( $M k t V o l)$, QIB investors' demand multiple (LnDmtlQIB), gross proceeds (LnGpcds) as explanatory variables. We also include a dummy variable to control for industry effects (Hi-Tech), a dummy variable to control for the two mechanisms (mechanism) and dummy variables to control for year fixed effects. Results of the regression analysis are presented in Table 7 where in regressions (1), (2) and (3) the dependent variables are the first day, first week and first month allocation weighted market adjusted initial returns respectively.

\section{<<Insert Table 7 here $>>$}

As shown in Table 7, LnDmtlQIB is positive and statistically significant across all the three regressions. Further, while the $\mathrm{MktVol}$ is positive and significant for the first day and first week returns, it is insignificant for the first month returns. $M k t 3 M w$, is insignificant in all the three regressions. This is because, as shown in Table 4, LnDmtlQIB is highly influenced by $M k t 3 M w$ and hence some variation in $M k t 3 M w$ is captured by the variation in $L n D m t l Q I B$. Other variables do not appear to have any significant impact on the allocation weighted initial returns. Thus, the findings show that retail investors can significantly enhance their allocation weighted initial returns by subscribing to IPOs with high QIB demand. 


\section{$<<$ Insert Table 8 here $>>$}

To further examine the allocation weighted returns that retail investors can earn by conditioning their subscription on QIB demand we analyse $A W M I R$ by quartile of QIB investors' demand. The analysis presented in Table 8 shows that retail investors can earn positive initial returns by only subscribing to those IPOs in which QIB demand is above average. The findings show that retail investors can significantly enhance their allocation weighted initial returns by avoiding IPOs with very low QIB demand. In fact, the difference in $A W M I R_{30}$ between IPOs with below median and above median QIB demand is $17.64 \%$ and the difference is highly significant. Since retail investors do not have to compete directly with institutional investors, they can earn returns which are significantly higher than zero even when institutional demand is high.

\section{Conclusions}

One of the most controversial features of the bookbuilding mechanism, as it is practised in the US and in most other markets, is its complete lack of transparency. In general, the bookbuilding mechanism is opaque and offers little information on how different investors participate in IPOs and how underwriters set the IPO offer price. This lack of transparency has not only hindered our understanding of the IPO process, it has also, as critics of bookbuilding argue, encouraged quid pro quo relationship between underwriters and institutional investors. The Indian IPO market provides us with a unique setting where the bookbuilding is far more transparent and as a consequence investors are able to observe the demand of prior investors. The transparency in the Indian IPO mechanism enables us to examine the complete demand schedule, demand over time as well as the demand of different investor categories in both auction and a modified version of 
bookbuilding mechanism. We use the Indian setting to examine investors' participation, and in particular the participation of retail investors, and its impact on IPO pricing.

Using a sample of 306 IPOs over a 10 year period from January 2001 to December 2010, we find that the transparency in the IPO mechanism creates demand which is concentrated at either one or two points of the offer price range. Analysis of evolution of demand over the offer period reveals that while large institutional investors, owing to their superior information, subscribe early compared to other investor categories, retail investors appear to follow institutional investors. We find that favourable demand by retail investors is one of the most significant contributors to high IPO offer prices and our results hold even when we control for the demand by informed institutional investors. Finally, our examination of allocation weighted initial returns suggests that, on average, retail investors are unlikely to make positive initial returns even in a setting where they do not have to compete with institutional investors. Retail investors, however, can make significant positive initial returns if they limit their participation in only those IPOs which attract above average demand from well informed institutional investors. 
Appendix A: Live Bookbuilding on the Bombay Stock Exchange (BSE) Website

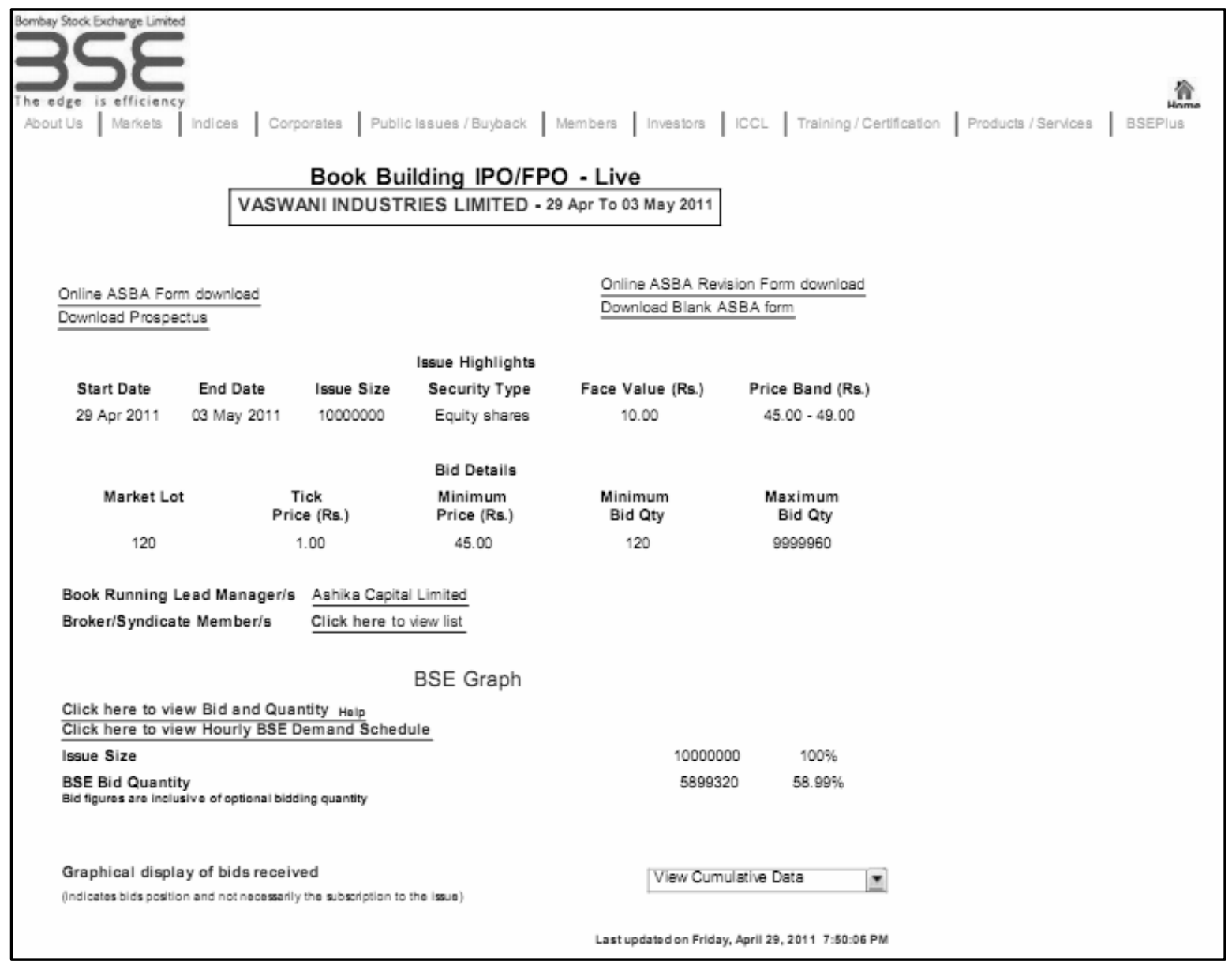

This figure shows the information available on the live bookbuilding page on the Bombay Stock Exchange website available at www.bseindia.com. The information is also available on the National Stock Exchange website site at www.nseindia.com. 


\section{Appendix B: List of Qualified Institutional Buyers (QIB)}

1 Mutual fund, Venture Capital Fund and Foreign Venture Capital Investor

Foreign Institutional Investor and Sub-Account (Other Than a Sub-Account which is a Foreign

2 Corporate or Foreign Individual), registered with the board

3 Public Financial Institution as defined in S 4A of the Companies Act,1956

4 Schedule Commercial Bank

$5 \quad$ Multilateral and Bilateral Development Financial Institution

6 State Industrial Development Corporation

7 Insurance Company registered with the Insurance Regulatory and Development Authority

8 Provident Fund with minimum corpus of two hundred million Indian Rupees

9 Pension Fund with minimum corpus of two hundred and fifty million Indian Rupees

National Investment Fund set up by resolution F.No. 2/3/2005- DDII dated November, 23, 2005 of

10 the Government of India published in the Gazette of India

11 Insurance funds set up and managed by army, navy or air force of the Union of India.

This table shows the list of institutions and funds, when registered with the Securities and Exchange Board of India (SEBI) are considered to be Qualified Institutional Buyers (QIB).

Source: Securities and Exchange Board of India (SEBI). 


\section{References}

Aggarwal, R., Prabhala, N.R., Puri, M., 2002. Institutional allocation in initial public offerings: Empirical evidence. Journal of Finance 57, 1421-1442.

Amihud, Y., Hauser, S., Kirsh, A., 2003. Allocations, adverse selection, and cascades in IPOs: Evidence from the Tel Aviv Stock Exchange. Journal of Financial Economics 68, 137-158.

Baron, D.P., 1982. A model of the demand for investment banking advising and distribution services for new issues. Journal of Finance 37, 955-976.

Baron, D.P., Holmstrom, B., 1980. The investment banking contract for new issues under asymmetric information: Delegation and the incentive problem. Journal of Finance 35, 11151138.

Benveniste, L.M., Spindt, P.A., 1989. How investment bankers determine the offer price and allocation of new issues. Journal of Financial Economics 24, 343-361.

Benveniste, L.M., Wilhelm, W.J., 1990. A comparative analysis of IPO proceeds under alternative regulatory environments. Journal of Financial Economics 28, 173-207.

Biais, B., Bossaerts, P., Rochet, J.C., 2002. An optimal IPO mechanism. The Review of Economic Studies 69, 117-146.

Biais, B., Faugeron-Crouzet, A.M., 2002. IPO auctions: English, Dutch, ... French, and internet. Journal of Financial Intermediation 11, 9-36.

Bubna, A., Prabhala, N.R., 2010. IPOs with and without allocation discretion: Empirical evidence. Journal of Financial Intermediation 20, 530-561.

Chiang, Y., Qian, Y., Sherman, A., 2010. Endogenous entry and partial adjustment in IPO auctions: Are institutional investors better informed? Review of Financial Studies 23, 12001230 .

Cornelli, F., Goldreich, D., 2003. Bookbuilding: How informative is the order book? Journal of Finance 58, 1415-1443.

Deb, S.S., Marisetty, V.B., 2010. Information content of IPO grading. Journal of Banking and Finance 34, 2294-2305.

Degeorge, F., Derrien, F., Womack, K., 2010. Auctioned IPOs: The US evidence. Journal of Financial Economics 98, 177-194.

Derrien, F., 2005. IPO pricing in "hot" market conditions: Who leaves money on the table? Journal of Finance 60, 487-521. 
Hanley, K.W., 1993. The underpricing of initial public offerings and the partial adjustment phenomenon. Journal of Financial Economics 34, 231-250.

Hanley, K.W., Wilhelm, W.J., 1995. Evidence on the strategic allocation of initial public offerings. Journal of Financial Economics 37, 239-257.

Hao, Q., 2007. Laddering in initial public offerings. Journal of Financial Economics 85, 102-122.

Jenkinson, T., Jones, H., 2004. Bids and allocations in European IPO bookbuilding. Journal of Finance 59, 2309-2338.

Jenkinson, T., Jones, H., 2009. IPO pricing and allocation: A survey of the views of institutional investors. Review of Financial Studies 22, 1477-1504.

Kandel, S., Sarig, O., Wohl, A., 1999. The demand for stocks: An analysis of IPO auctions. Review of Financial Studies 12, 227-247.

Keloharju, M., 1993. The winner's curse, legal liability, and the long-run price performance of initial public offerings in Finland. Journal of Financial Economics 34, 251-277.

Koh, F., Walter, T., 1989. A direct test of Rock's model of the pricing of unseasoned issues. Journal of Financial Economics 23, 251-272.

Lakonishok, J., Shleifer, A., Vishny, R.W., 1992. The impact of institutional trading on stock prices. Journal of Financial Economics 32, 23-43.

Levis, M., 1990. The winner's curse problem, interest costs and the underpricing of initial public offerings. Economic Journal 100, 76-89.

Lin, J.C., Lee, Y.T., Liu, Y.J., 2007. IPO auctions and private information. Journal of Banking and Finance 31, 1483-1500.

Loughran, T., Ritter, J.R., 2002. Why don't issuers get upset about leaving money on the table in IPOs? Review of Financial Studies 15, 413-444.

Purnanandam, A., Swaminathan, B., 2004. Are IPOs really underpriced? Review of Financial Studies 17, 811-848.

Reuter, J., 2006. Are IPO allocations for sale? Evidence from mutual funds. Journal of Finance 61, 2289-2324.

Ritter, J.R., Zhang, D., 2007. Affiliated mutual funds and the allocation of initial public offerings. Journal of Financial Economics 86, 337-368.

Rocholl, J., 2009. A friend in need is a friend indeed: Allocation and demand in IPO bookbuilding. Journal of Financial Intermediation 18, 284-310.

Rock, K., 1986. Why new issues are underpriced. Journal of Financial Economics 15, 187-212. 
Sherman, A.E., 2000. IPOs and long-term relationships: An advantage of book building. Review of Financial Studies 13, 697-714.

Shleifer, A., Summers, L.H., 1990. The noise trader approach to finance. The Journal of Economic Perspectives 4, 19-33. 
Table 1: Descriptive Statistics of Sample by Year

\begin{tabular}{|c|c|c|c|c|c|c|c|c|c|c|c|c|}
\hline Particulars & 2001 & 2002 & 2003 & 2004 & 2005 & 2006 & 2007 & 2008 & 2009 & 2010 & Total & Median \\
\hline Number of IPOs & 2 & 2 & 3 & 12 & 39 & 56 & 84 & 32 & 19 & 57 & 306 & \\
\hline Bookbuilding Issues & 2 & 2 & 3 & 12 & 32 & 1 & & & & & 52 & \\
\hline Auction Issues & & & & & 7 & 55 & 84 & 32 & 19 & 57 & 254 & \\
\hline Average Age at IPO & 13.55 & 9.63 & 11.50 & 17.76 & 12.55 & 13.22 & 14.31 & 13.40 & 14.65 & 15.94 & 14.19 & 12.21 \\
\hline Average Total Assets (M INR) & 625 & 25,727 & 19,029 & 5,079 & 6,483 & 5,738 & 5,998 & 3,534 & 13,509 & 8,508 & 6,874 & 1,945 \\
\hline Average Gross Proceeds (M INR) & 479 & 5,220 & 3,560 & 5,441 & 2,552 & 2,974 & 3,311 & 4,790 & 5,521 & 3,366 & 3,535 & 1,128 \\
\hline Leverage & 0.41 & 0.08 & 0.42 & 0.48 & 0.50 & 0.60 & 0.60 & 0.54 & 0.53 & 0.59 & 0.56 & 0.60 \\
\hline Raw First Day Returns $\left(\mathrm{IR}_{1}\right)$ & -0.41 & -0.04 & 0.45 & 0.50 & 0.35 & 0.20 & 0.28 & 0.11 & 0.10 & 0.13 & 0.22 & 0.13 \\
\hline Market Adjusted First Day Returns $\left(\mathrm{MIR}_{1}\right)$ & -0.20 & -0.08 & 0.37 & 0.50 & 0.32 & 0.17 & 0.27 & 0.16 & 0.08 & 0.12 & 0.21 & 0.10 \\
\hline Market Adjusted One Month Return $\left(\mathrm{MIR}_{30}\right)$ & -0.10 & -0.15 & 0.30 & 0.49 & 0.40 & 0.23 & 0.25 & -0.01 & -0.03 & 0.01 & 0.18 & 0.08 \\
\hline Average Total Demand Multiple & 1.18 & 2.53 & 15.39 & 28.85 & 24.20 & 19.00 & 30.59 & 9.31 & 6.18 & 15.53 & 20.51 & 8.08 \\
\hline Average QIB Demand Multiple & 1.55 & 2.91 & 10.14 & 17.14 & 23.87 & 25.69 & 37.17 & 11.10 & 10.10 & 17.45 & 23.94 & 8.08 \\
\hline Average NII Demand Multiple & 1.34 & 1.97 & 34.29 & 60.16 & 44.97 & 25.07 & 41.91 & 11.91 & 5.63 & 35.30 & 32.93 & 8.76 \\
\hline Average RII Demand Multiple & 0.66 & 1.17 & 9.40 & 26.02 & 20.24 & 8.66 & 15.05 & 4.21 & 2.10 & 7.94 & 11.55 & 4.75 \\
\hline Average IPO Offer Price (Normalized) & 0.50 & 0.00 & 1.00 & 0.88 & 0.90 & 0.80 & 0.85 & 0.70 & 0.79 & 0.74 & 0.80 & 1.00 \\
\hline Average Limit Price (Normalized) & 0.22 & 0.09 & 0.53 & 0.09 & 0.25 & 0.26 & 0.22 & 0.15 & 0.23 & 0.21 & 0.22 & 0.21 \\
\hline IPOs with +ve First Day Return & 0 & 0 & 3 & 12 & 32 & 31 & 51 & 19 & 11 & 36 & 195 & \\
\hline IPOs with -ve First Day Returns & 2 & 2 & 0 & 0 & 7 & 25 & 33 & 13 & 8 & 21 & 111 & \\
\hline
\end{tabular}

This table reports the descriptive statistics of Indian IPO by year. The sample includes IPOs listed on the BSE and NSE from January 2001 to December 2010. Age is the difference between a firm's IPO year and the founding year. Total assets is the total assets of the firm for the quarter prior to the IPO as reported in the offer document. Gross proceeds is the gross proceeds of the offer calculated by multiplying the offer price with the number of shares offered. Leverage is the ratio of total liabilities to total assets for the last quarter prior to the IPO. Raw first day return $\left(\operatorname{IR}_{l}\right)$ is the simple return calculated between IPO offer price and the closing price at the end of the first day of trading. Market adjusted first day return $\left(M I R_{1}\right)$ is the difference between raw first day return (IR) and the market returns over the same period of time. Market return is the simple return calculated between the index value on the offer date and the date of listing. We use the BSE Sensex as our measure of the market return. Market adjusted one month return is the difference between the simple one month IPO return and the market return over the same period of time. Total demand multiple is the ratio of the investors' demand for shares (at and above the offer price) and the total number of shares offered. QIB demand multiple is the ratio of the Qualified Institutional Buyers' (QIBs) demand for shares (at and above the offer price) and the total number of shares offered to the QIB category. NII demand multiple is the ratio of the Non-Institutional Investors' (NIIs) demand for shares (at and above the offer price) and the total number of shares offered to the NII category. RII demand multiple is the ratio of the Retail Individual Investors' (RIIs) demand for shares (at and above the offer price) and the total number of shares offered to the RII category. IPO offer price (normalized) is the normalized issue offer price by the initial price range. Limit price (normalized) is the quantity weighted average of all limit prices normalized by the initial offer price range. (1 US\$ approximately equal to INR 45). 
Table 2: Descriptive Statistics: Aggregate Demand Schedule

Panel A: Investor's demand at different points of the offer price range-by IPO

\begin{tabular}{|c|c|c|c|c|c|c|}
\hline & Lower Bound & Below Mid-Point & Mid-Point & Above Mid-Point & Upper Bound & No of Obs. \\
\hline Overall Sample & 7.24 & 2.50 & 1.97 & 1.17 & 86.97 & 281 \\
\hline Bookbuilding & 16.16 & 5.59 & 2.10 & 3.06 & 73.01 & 240 \\
\hline Auction & 5.71 & 1.97 & 1.95 & 0.84 & 89.35 & 41 \\
\hline \multicolumn{7}{|l|}{ Wilcoxon Z statistics } \\
\hline Bookbuilding -Auction (z) & 0.341 & 1.456 & 1.541 & 1.575 & -0.432 & \\
\hline Prob $>|z|$ & $(0.7330)$ & $(0.1453)$ & $(0.1232)$ & $(0.1153)$ & $(0.6661)$ & \\
\hline
\end{tabular}

Panel B: Proportion of strike bids submitted by investors

\begin{tabular}{lrr} 
Panel B: Proportion of strike bids submitted by investors & Auction \\
\hline \% Strike Bids by Investors & Bookbuilding & 14 \\
\hline Less than 30\% & 5 & 14 \\
$30-60 \%$ & 0 & 19 \\
$60-70 \%$ & 2 & 5 \\
$70-80 \%$ & 0 & 13 \\
$80-90 \%$ & 4 & 23 \\
$90-95 \%$ & 5 & 23 \\
$95-99 \%$ & 5 & 27 \\
More than 99\% & 9 & 53 \\
Total & 16 & 62 \\
\hline
\end{tabular}

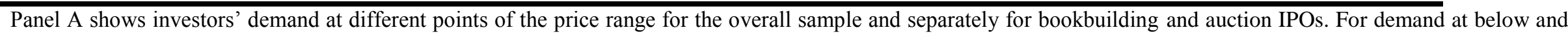

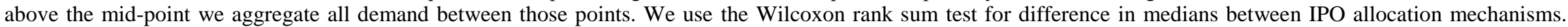

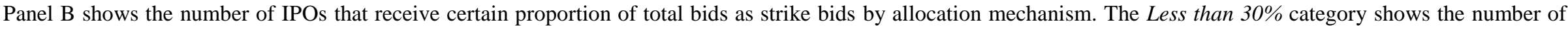

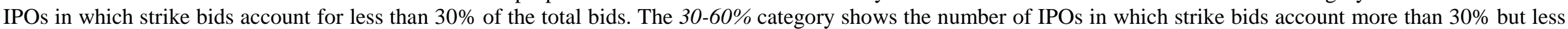

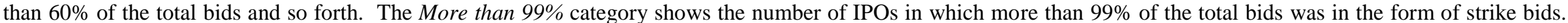

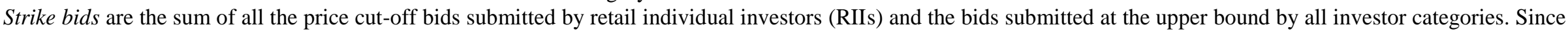
the Indian IPO price range has never been revised upward, submitting a bid at the upper bound of the price range is effectively submitting a strike bid.
} 
Table 3: Demand Over-time

Panel A: Number of fully subscribed IPOs by the end of each bidding day

\begin{tabular}{lrrrr}
\hline Cumulative Demand & Day 0 & Day 1 & Day 2 & Day 3 \\
\hline Institutional Investors (QIBs) & 156 & 109 & 69 & 35 \\
Non-Institutional Investors (NIIs) & 171 & 95 & 59 & 7 \\
Retail Investors (RIIs) & 153 & 46 & 20 & 7 \\
Total & 193 & 89 & 56 & 6 \\
\hline
\end{tabular}

Panel B : Cumulative demand over the bidding period by strength of QIBs demand

\begin{tabular}{|c|c|c|c|c|c|}
\hline Cumulative Demand & Day 0 & Day 1 & Day 2 & Day 3 & Day 4 \\
\hline \multicolumn{6}{|l|}{ Strong Demand $(N=69)$} \\
\hline \multicolumn{6}{|c|}{ Institutional Investors (QIBs) } \\
\hline Mean & 48.2549 & 9.4530 & 3.5355 & 1.7468 & 0.3614 \\
\hline Median & 33.8607 & 4.9975 & 2.3056 & 0.9531 & 0.0000 \\
\hline $\mathrm{SD}$ & 50.1222 & 11.5572 & 3.6303 & 2.7849 & 1.0994 \\
\hline \multicolumn{6}{|c|}{ Non-Institutional Investors (NIIs) } \\
\hline Mean & 57.7188 & 2.5369 & 1.3359 & 0.6297 & 0.1193 \\
\hline Median & 31.4805 & 0.6882 & 0.1811 & 0.0058 & 0.0000 \\
\hline $\mathrm{SD}$ & 68.9360 & 4.7335 & 2.3090 & 1.6242 & 0.8328 \\
\hline \multicolumn{6}{|l|}{ Retail Investors (RIIs) } \\
\hline Mean & 16.9954 & 1.8301 & 0.7070 & 0.1482 & 0.0145 \\
\hline Median & 9.4057 & 0.5250 & 0.1952 & 0.0300 & 0.0000 \\
\hline $\mathrm{SD}$ & 22.7582 & 3.1549 & 1.3242 & 0.2999 & 0.0539 \\
\hline \multicolumn{6}{|l|}{ Weak Demand $(N=126)$} \\
\hline \multicolumn{6}{|c|}{ Institutional Investors (QIBs) } \\
\hline Mean & 10.7327 & 1.6490 & 0.2707 & 0.0962 & 0.0279 \\
\hline Median & 1.9787 & 0.6394 & 0.2000 & 0.0000 & 0.0000 \\
\hline $\mathrm{SD}$ & 21.9296 & 3.6925 & 0.2903 & 0.2149 & 0.1141 \\
\hline \multicolumn{6}{|c|}{ Non-Institutional Investors (NIIs) } \\
\hline Mean & 18.1568 & 1.5494 & 0.9973 & 0.2999 & 0.1066 \\
\hline Median & 4.5951 & 1.0019 & 0.3978 & 0.0000 & 0.0000 \\
\hline SD & 35.5539 & 1.9305 & 1.5817 & 0.6448 & 0.3947 \\
\hline \multicolumn{6}{|l|}{ Retail Investors (RIIs) } \\
\hline Mean & 5.7419 & 0.5062 & 0.2607 & 0.1123 & 0.0433 \\
\hline Median & 2.8865 & 0.3241 & 0.1084 & 0.0062 & 0.0000 \\
\hline SD & 7.8337 & 0.5435 & 0.3949 & 0.2612 & 0.1838 \\
\hline \multicolumn{6}{|l|}{ Wilcoxon z-statistics } \\
\hline QIBs = Weak - Strong & $-6.687 * * *$ & $-9.159 * * *$ & $-11.635 * * *$ & $-7.251 * * *$ & $-3.076 * * *$ \\
\hline NIIs = Weak - Strong & $-3.603 * * *$ & -0.294 & -0.682 & -1.246 & 0.024 \\
\hline RIIs = Weak - Strong & $-3.845 * * *$ & $-3.088 * * *$ & $-2.809 * * *$ & $-2.607 * * *$ & -0.568 \\
\hline
\end{tabular}

Panel A shows the number of IPOs in which the shares reserved for various investor categories are fully subscribed over the offer period. Day 0 is the final bidding day of the offer period while Day 4 is the first day of offer for most of the sample IPOs. The sample consists of 195 auction IPOs for which we have data on investors' participation over time. There are two IPOs in which the total demand multiple is just below 1. Panel B shows the number of IPOs in which the shares reserved for various investor categories are fully subscribed over the offer period by IPOs with strong and weak QIBs (institutional investors) demand. IPOs are considered to be strong if QIBs fully subscribe to their portion of the offer by the end of the third day of bidding period (Day 2 in this table). We use the Wilcoxon rank sum test for the difference in median in investor participation between the two IPO categories. $* * *$ denote the difference is significant at less than $1 \%$ level. 
Table 4: Determinants of investors' participation overtime: OLS regression

\begin{tabular}{|c|c|c|c|c|c|}
\hline & $\begin{array}{l}\mathrm{QIB}_{1} \\
(1)\end{array}$ & $\begin{array}{l}\mathrm{NII}_{1} \\
(2)\end{array}$ & $\begin{array}{l}\mathrm{RII}_{0} \\
(3)\end{array}$ & $\begin{array}{c}\mathrm{RII}_{0}(\text { Strong }=1) \\
(4)\end{array}$ & $\begin{array}{c}\mathrm{RII}_{0}(\text { Strong }=0) \\
(5)\end{array}$ \\
\hline $\mathrm{LnDmtlQIB}_{2}$ & & $\begin{array}{c}0.303 * * * \\
(3.18)\end{array}$ & & & \\
\hline LnDmtlQIB $_{1}$ & & & $\begin{array}{c}0.807 * * * \\
(10.71)\end{array}$ & $\begin{array}{c}0.9268 * * * \\
(6.60)\end{array}$ & $\begin{array}{c}0.5887 * * * \\
(5.44)\end{array}$ \\
\hline LnGpcds & $\begin{array}{c}0.234 * * * \\
(3.63)\end{array}$ & $\begin{array}{l}0.0386 \\
(0.61)\end{array}$ & $\begin{array}{c}-0.431 * * * \\
(-6.97)\end{array}$ & $\begin{array}{c}-0.4680 * * * \\
(-6.46)\end{array}$ & $\begin{array}{c}-0.3585^{* * *} \\
(-3.23)\end{array}$ \\
\hline LbmRep & $\begin{array}{c}0.387 * * * \\
(2.82)\end{array}$ & $\begin{array}{c}-0.415 * * * \\
(-3.71)\end{array}$ & $\begin{array}{l}-0.106 \\
(-0.66)\end{array}$ & $\begin{array}{c}-0.1234 \\
(-0.47)\end{array}$ & $\begin{array}{c}-0.1541 \\
(-0.68)\end{array}$ \\
\hline Mkt3Mw & $\begin{array}{c}2.186^{* *} \\
(2.01)\end{array}$ & $\begin{array}{l}1.001 \\
(1.17)\end{array}$ & $\begin{array}{c}3.859 * * * \\
(5.53)\end{array}$ & $\begin{array}{c}3.1167 * * \\
(2.59)\end{array}$ & $\begin{array}{c}4.0613^{* * * *} \\
\quad(4.67)\end{array}$ \\
\hline MktVol & $\begin{array}{l}6.867 \\
(0.53)\end{array}$ & $\begin{array}{l}-2.013 \\
(-0.24)\end{array}$ & $\begin{array}{c}-20.69 * * * \\
(-2.99)\end{array}$ & $\begin{array}{l}-16.95 \\
(-1.47)\end{array}$ & $\begin{array}{c}-23.47 * * \\
(-2.49)\end{array}$ \\
\hline HiTech & $\begin{array}{l}0.245 \\
(1.36)\end{array}$ & $\begin{array}{c}-0.277 * * \\
(-2.08)\end{array}$ & $\begin{array}{l}-0.058 \\
(-0.39)\end{array}$ & $\begin{array}{l}-0.1203 \\
(-0.49)\end{array}$ & $\begin{array}{l}-0.1511 \\
(-0.07)\end{array}$ \\
\hline Year fixed effect & Yes & Yes & Yes & Yes & Yes \\
\hline Constant & $\begin{array}{c}-1.136 * * \\
(-2.57)\end{array}$ & $\begin{array}{l}0.439 \\
(1.17)\end{array}$ & $\begin{array}{c}4.167 * * * \\
(9.60)\end{array}$ & $\begin{array}{c}4.2631 * * * \\
(6.84)\end{array}$ & $\begin{array}{c}3.8106^{* * *} \\
(5.01)\end{array}$ \\
\hline $\begin{array}{l}\text { Observations } \\
\text { Adjusted } R^{2}\end{array}$ & $\begin{array}{c}195 \\
0.285\end{array}$ & $\begin{array}{c}195 \\
0.133\end{array}$ & $\begin{array}{c}195 \\
0.535\end{array}$ & $\begin{array}{c}69 \\
0.688\end{array}$ & $\begin{array}{c}126 \\
0.318\end{array}$ \\
\hline
\end{tabular}

This table reports the OLS regression on the participation of different investor categories over time on a sample of 195 auction IPOs. The dependent variable in regressions (1) and (2) is the logarithm of one plus demand multiple at the end of the penultimate day of the offer period for Qualified Institutional Buyers $\left(\right.$ LnDmtlQIB $\left._{l}\right)$ and Non-Institutional Investors $\left(\mathrm{LnDmtlNII}_{l}\right)$ respectively. The dependent variable in regressions (3) to (5) is the demand multiple at the end of the bidding period for Retail Individual Investors $\left(R I I_{0}\right) . L n D m t l Q I B_{2}$ is the logarithm of one plus the demand multiple of QIBs two days prior to the end of the bidding period. LbmRep is a binary variable which equals 1 for reputed underwriters and 0 otherwise. LnGpcds is the logarithm of gross proceeds. $M k t 3 M w$ is the weighted average of the buyand-hold returns on the BSE Sensex index in the three months before the IPO date where weights are 3 for the recent month, 2 for the next and 1 for the third month before the offering. MktVol is standard deviation of the index returns one month prior to the offer issue date. HiTech is a dummy variable with a value of 1 for IPOs in the information technology and biotechnology industries and 0 otherwise. White heteroskedasticity-consistent $t$ - statistics are in parentheses. ${ }^{* * *}$ and ** indicate statistical significance at less than $1 \%$ and $5 \%$ levels. 
Table 5: Determinants of the offer price

\begin{tabular}{|c|c|c|c|c|c|c|}
\hline & (1) & (2) & (3) & (4) & (5) & (6) \\
\hline AvLimitPr & $\begin{array}{c}5.825 * * * \\
(4.56)\end{array}$ & & $\begin{array}{c}3.104 * * * \\
(3.31)\end{array}$ & $\begin{array}{l}1.476^{*} \\
(1.93)\end{array}$ & $\begin{array}{l}1.109 * \\
(1.86)\end{array}$ & \\
\hline LnDmtl & & $\begin{array}{c}1.102 * * * \\
(5.62)\end{array}$ & $\begin{array}{c}1.012 * * * \\
(5.24)\end{array}$ & $\begin{array}{c}0.790 * * * \\
(4.91)\end{array}$ & & \\
\hline LnDmtlQIB & & & & & $\begin{array}{c}0.319 * * \\
(2.31)\end{array}$ & $\begin{array}{c}0.357 * * \\
(2.46)\end{array}$ \\
\hline LnDmtlNII & & & & & $\begin{array}{c}-0.00340 \\
(-0.03)\end{array}$ & $\begin{array}{c}-0.0140 \\
(-0.10)\end{array}$ \\
\hline LnDmtlRII & & & & & $\begin{array}{c}0.918 * * * \\
(4.02)\end{array}$ & $\begin{array}{c}1.157 * * * \\
(4.70)\end{array}$ \\
\hline Elasticity & & & & $\begin{array}{c}-0.0582 * * * \\
(-4.53)\end{array}$ & $\begin{array}{c}-0.0247 * * * \\
(-2.74)\end{array}$ & \\
\hline LbmRep & & & & & $\begin{array}{c}-1.583 * * * \\
(-4.67)\end{array}$ & $\begin{array}{c}-1.660 * * * \\
(-4.77)\end{array}$ \\
\hline LnGpcds & & & & & $\begin{array}{c}0.00269 \\
(0.03)\end{array}$ & $\begin{array}{l}-0.104 \\
(-1.02)\end{array}$ \\
\hline Hi-Tech & & & & & $\begin{array}{l}0.164 \\
(0.47)\end{array}$ & $\begin{array}{l}0.225 \\
(0.67)\end{array}$ \\
\hline Mkt3Mw & & & & & $\begin{array}{c}2.995 * \\
(1.77)\end{array}$ & $\begin{array}{l}2.957 * \\
(1.72)\end{array}$ \\
\hline MktVol & & & & & $\begin{array}{l}10.44 \\
(0.62)\end{array}$ & $\begin{array}{l}1.968 \\
(0.11)\end{array}$ \\
\hline Mechanism & & & & & $\begin{array}{c}-0.0145 \\
(-0.05)\end{array}$ & $\begin{array}{l}-0.300 \\
(-1.00)\end{array}$ \\
\hline Year fixed effect & Yes & Yes & Yes & Yes & Yes & Yes \\
\hline Constant & $\begin{array}{c}1.859 * * * \\
(6.62)\end{array}$ & $\begin{array}{c}1.631 * * * \\
(6.96)\end{array}$ & $\begin{array}{c}1.495 * * * \\
(6.74)\end{array}$ & $\begin{array}{c}1.284 * * * \\
(6.80)\end{array}$ & $\begin{array}{c}0.915^{* * * *} \\
(7.01)\end{array}$ & $\begin{array}{c}1.026 * * * \\
(7.22)\end{array}$ \\
\hline $\begin{array}{l}\text { Observations } \\
\text { Left-censored Obs. } \\
\text { Right-censored Obs. } \\
\text { Log likelihood }\end{array}$ & $\begin{array}{c}281 \\
40 \\
201 \\
-198.85\end{array}$ & $\begin{array}{c}306 \\
42 \\
224 \\
-193.74\end{array}$ & $\begin{array}{c}281 \\
40 \\
201 \\
-167.27\end{array}$ & $\begin{array}{c}281 \\
40 \\
201 \\
-149.62\end{array}$ & $\begin{array}{c}281 \\
40 \\
201 \\
-113.44\end{array}$ & $\begin{array}{c}306 \\
42 \\
224 \\
-134.62\end{array}$ \\
\hline
\end{tabular}

This table reports the regression coefficients of the Tobit regression model examining the determinants of offer price. The dependent variable is the offer price normalized by the initial offer price range. Average Limit Price (AvLimitPr) is the quantity-weighted average of all limit prices and is normalized by the initial offer price range. LnDmtl, LnDmtlQIB, LnDmtlNII and LnDmtlRII are the logarithms of one plus demand multiple (total share bid at or above the offer price divided by the total shares offered) of total offer, qualified institutional buyers (QIB), noninstitutional investors (NII) and retail individual investors (RII) respectively. Elasticity is the elasticity of demand computed from the lower bound of the demand schedule to the average quantity adjusted limit price. LbmRep is a binary variable which equals 1 for reputed underwriters and 0 otherwise for regressions. LnGpcds is the logarithm of gross proceeds. $M k t 3 M w$ is the weighted average of the buy-and-hold returns on the BSE Sensex index in the three months before the IPO date where weights are 3 for the recent month, 2 for the next and 1 for the third month before the offering. MktVol is standard deviation of the index returns one month prior to the offer issue date. HiTech is a dummy variable with a value of 1 for IPOs in the information technology and biotechnology industries and 0 otherwise. Mechanism is a dummy variable which takes the value of 1 for bookbuilding IPOs and 0 for auction IPOs. Robust $t$ - statistics are in parentheses. ***, ** and * indicate statistical significance at less than $1 \%, 5 \%$ and $10 \%$ levels. 
Table 6: Allocation weighted initial returns for retail investors

\begin{tabular}{lccccc}
\hline Sum & Mean & Median & Skewness & Minimum & Maximum \\
\hline $\operatorname{AWIR}_{1}(\%)$ & 0.2469 & 0.3200 & 2.0469 & -274.96 & 290.01 \\
& $(0.1144)$ & $(1.1310)$ & & & \\
$\operatorname{AWIR}_{7}(\%)$ & -1.5983 & 0.4700 & 2.9301 & -224.22 & 432.42 \\
& $(-0.6328)$ & $(0.2310)$ & & -262.85 & 299.76 \\
$\operatorname{AWIR}_{30}(\%)$ & -6.5682 & -0.1300 & -0.5586 & & \\
& $(-2.4952)$ & $(-2.0690)$ & & & \\
\hline
\end{tabular}

This table reports the allocation weighted market adjusted initial returns (MIR) for retail investors (RIIs). AWMIR,$A W M I R_{7}$ and $A W M I R_{30}$ are the first day, first week and first month allocation weighted initial returns. Allocation weighted initial return is calculated as initial returns divided by RII demand multiple less the interest expenses. We use the State Bank of India's (SBI) advance interest rates for calculating interest expense. The $t$ and $z$ statistics test that the mean and median are different from zero. 
Figure 1: Allocation weighted initial returns for retail investors

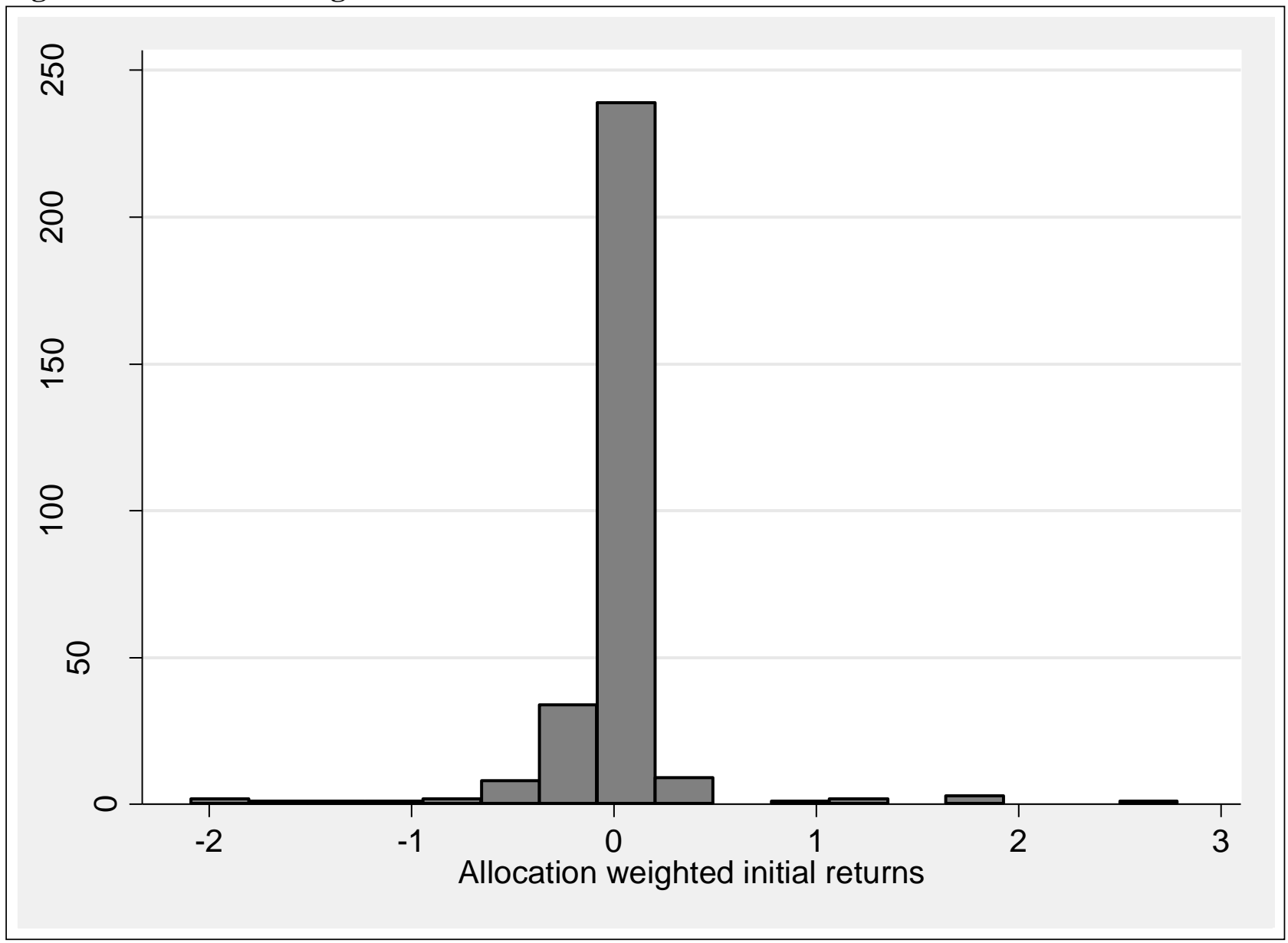

This figure shows the distribution of the first month allocation weighted market adjusted initial returns for retail investors. Allocation weighted initial return is calculated as initial returns divided by RII demand multiple less the interest expenses. We use the State Bank of India's (SBI) advance interest rates for calculating interest expense. 
Figure 2: Initial returns and allocation weighted initial returns for retail investors

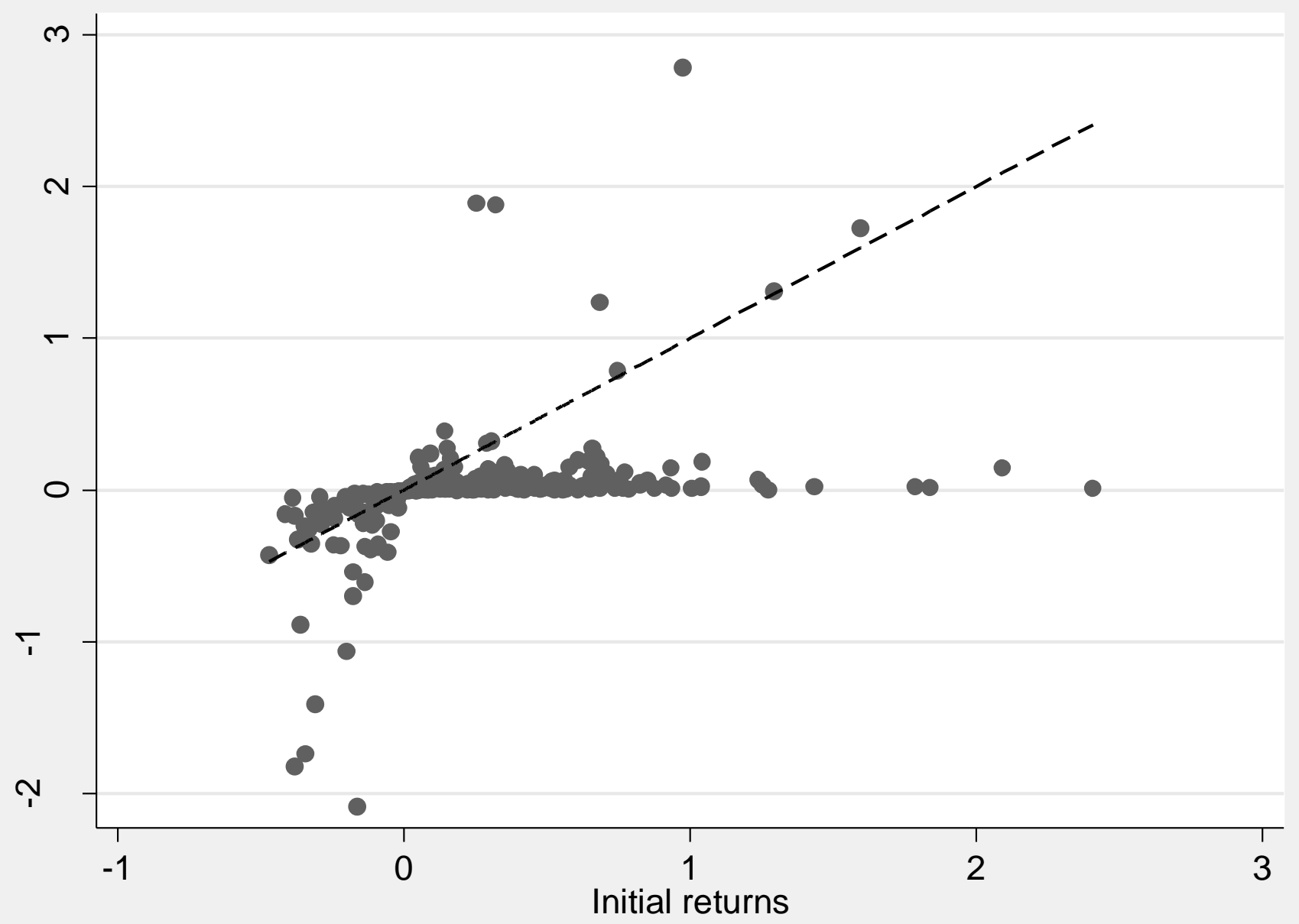

This figure presents the scatter plot for first day market adjusted initial returns and the allocation weighted market adjusted initial returns for retail investors. Allocation weighted initial return is calculated as initial returns divided by RII demand multiple less the interest expenses. We use the State Bank of India's (SBI) advance interest rates for calculating interest expense. 
Table 7: Conditional allocation weighted initial returns for retail investors

\begin{tabular}{|c|c|c|c|}
\hline & $\begin{array}{c}\mathrm{AWIR}_{1} \\
\text { (1) }\end{array}$ & $\begin{array}{c}\mathrm{AWIR}_{7} \\
\text { (2) }\end{array}$ & $\begin{array}{c}\mathrm{AWIR}_{30} \\
(3)\end{array}$ \\
\hline Mkt3Mw & $\begin{array}{c}0.3563 \\
(0.71)\end{array}$ & $\begin{array}{c}0.2005 \\
(0.44)\end{array}$ & $\begin{array}{c}-0.3449 \\
(-0.67)\end{array}$ \\
\hline MktVol & $\begin{array}{c}19.252 * * * \\
(3.06)\end{array}$ & $\begin{array}{c}21.032 * * * \\
\quad(2.70)\end{array}$ & $\begin{array}{l}78.66 \\
(1.54)\end{array}$ \\
\hline LnDmtlQIB & $\begin{array}{c}0.0491 * * * \\
(2.77)\end{array}$ & $\begin{array}{c}0.0622 * * * \\
\quad(3.22)\end{array}$ & $\begin{array}{c}0.0870 * * * \\
\quad(4.76)\end{array}$ \\
\hline LnGpcds & $\begin{array}{c}-0.0305^{*} \\
(-1.69)\end{array}$ & $\begin{array}{c}-0.0233 \\
(-0.94)\end{array}$ & $\begin{array}{c}-0.0342 \\
(-1.64)\end{array}$ \\
\hline Hi-Tech & $\begin{array}{c}0.0226 \\
(0.28)\end{array}$ & $\begin{array}{c}0.1671 \\
(1.34)\end{array}$ & $\begin{array}{c}0.0867 \\
(1.53)\end{array}$ \\
\hline Mechanism & $\begin{array}{c}0.0064 \\
(0.14)\end{array}$ & $\begin{array}{c}0.0186 \\
(0.32)\end{array}$ & $\begin{array}{l}-0.0005 \\
(-0.01)\end{array}$ \\
\hline Year fixed effect & Yes & Yes & Yes \\
\hline Constant & $\begin{array}{c}-0.1820 \\
(-0.90)\end{array}$ & $\begin{array}{c}-0.3550 \\
(-1.29)\end{array}$ & $\begin{array}{c}-0.1088 \\
(-0.42)\end{array}$ \\
\hline $\begin{array}{l}\text { Observations } \\
\text { Adjusted } R^{2}\end{array}$ & $\begin{array}{c}306 \\
0.098\end{array}$ & $\begin{array}{c}306 \\
0.099\end{array}$ & $\begin{array}{c}306 \\
0.051\end{array}$ \\
\hline
\end{tabular}

This table reports the regression coefficients of the OLS regression model which examines conditional allocation weighted initial returns for retail investors. The dependent variable in regressions (1), (2) and (3) is allocation weighted first day, first week and first month market adjusted initial returns respectively. We calculate allocation weighted market adjusted initial return by dividing market adjusted initial returns by RII demand multiple and subtracting it from interest expenses. $M k t 3 M w$ is the weighted average of the buyand-hold returns on the BSE Sensex index in the three months before the IPO date where weights are 3 for the recent month, 2 for the next and 1 for the third month before the offering. MktVol is standard deviation of the index returns one month prior to the offer issue date. LnDmtlQIB, is the logarithm of 1 plus demand multiple (total share bid at or above the offer price divided by the total shares offered) of qualified institutional buyers (QIBs). LnGpcds is the logarithm of gross proceeds. HiTech is a dummy variable with a value of 1 for IPOs in the information technology and biotechnology industries and 0 otherwise. Mechanism is a dummy variable which takes the value of 1 for bookbuilding IPOs and 0 for auction IPOs. Robust $t$ - statistics are in parentheses. *** and * indicate statistical significance at less than $1 \%$ and $10 \%$ levels. 
Table 8: Allocation weighted initial returns for retail investors by QIB's demand for shares

\begin{tabular}{|c|c|c|c|c|c|}
\hline \multicolumn{6}{|c|}{ Quartile of QIB Investors' Demand } \\
\hline & 1 (Low) & 2 & 3 & 4 (High) & $\begin{array}{c}\text { Diff } \\
\text { (Above 2- Below 2) }\end{array}$ \\
\hline \multirow[t]{2}{*}{ Mean AWMIR $1 \%$ ) } & -7.939 & -0.05 & 4.531 & 2.322 & 7.4216 \\
\hline & $(-1.0733)$ & $(-0.0156)$ & $(1.9056)$ & $(4.6196)$ & $(2.2815)$ \\
\hline \multirow[t]{2}{*}{ Mean $\mathrm{AWMIR}_{7}(\%)$} & -12.576 & -4.531 & 6.1377 & 2.1525 & 12.6985 \\
\hline & $(-1.4536)$ & $(-1.0865)$ & $(1.6667)$ & $(3.6551)$ & $(3.5825)$ \\
\hline \multirow[t]{2}{*}{ Mean AWMIR $30(\%)$} & -22.5667 & -6.578 & 4.0174 & 2.113 & 17.6378 \\
\hline & $(-2.9141)$ & $(-1.0067)$ & $(2.2528)$ & $(2.6925)$ & $(4.1623)$ \\
\hline \multicolumn{6}{|c|}{$\begin{array}{l}\text { In this table we report the allocation weighted market adjusted initial returns for retail investors according to the } \\
\text { quartile of QIB investors' demand. } A W M I R_{l}, A W M I R_{7}, \& A W M I R_{30} \text { are the allocation weighted market adjusted first } \\
\text { day, first week and first month initial returns. Market adjusted initial returns are raw initial returns adjusted by return } \\
\text { on the BSE Sensex over the same period of time. Allocation weighted market adjusted initial return is calculated as } \\
\text { market adjusted initial returns divided by RII demand multiple less the interest expenses. We use the State Bank of } \\
\text { India's (SBI) advance interest rates for calculating interest expense. Figures in parenthesis show } t \text {-statistics which } \\
\text { examine whether the mean is different from zero. Diff is the difference in } A W M I R \text { between IPOs with above and } \\
\text { below median QIB investors' demand. }\end{array}$} \\
\hline
\end{tabular}

